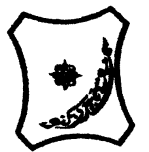

Bayero Journal of Pure and Applied Sciences, 9(2): 35 - 39

Received: April, 2016

Accepted: July, 2016

ISSN $2006-6996$

\title{
PREVALENCE OF TRICHOSTRONGYLID NEMATODE IN SHEEPS IN BENIN CITY, EDO STATE, NIGERIA
}

\author{
Omoruyi, Z. ${ }^{1 *}$, Aiguobasinmwin, E. L. ${ }^{1}$ and Shehu, A.Y. ${ }^{2}$ \\ ${ }^{* 1}$ Department of Medical Laboratory Science, College of Medical Sciences, School of Medical Sciences, University \\ of Benin, Edo State, Nigeria. \\ ${ }^{2}$ Ministry of Agriculture and Natural Resources, Kano \\ *Correspondence author
}

\begin{abstract}
Parasitism of Trichostrongylid nematode is a world-wide problem for both small and large scale farmers and is a great threat to the livestock industry and also a major constraint to the wellbeing and productive performance of ruminant animals. This study was carried out to determine the effect of Trichostrongylid nematode in sheep. The study was carried out in Aduwawa, Ugbiyokho, Oluku and Airport road in Edo State in 2015. A total of one hundred and fifty (150) sheep were examined for the present of gastrointestinal parasite. Sedimentation technique was used in examining the faecal sample for the presence of the GIT pararsites. The prevalence of eggs and larvae of $\mathrm{H}$. contortus were $71.3 \%$ and $15.3 \%$, Trichostrongylus species were $61.3 \%$ and $7.3 \%, 0$. ostertagii were $42.7 \%$ and 6.7\% respectively. Among 150 faecal sample examined, 103 (68.67\%) were found positive for Trichostrongylid infection. Grazing time, consistency of faeces and weight are factors having significant impact on the infection in sheep. Sheep that graze in the evening had the highest prevalence (82\%), faecal samples that were unformed had the highest prevalence $(85.71 \%)$ and sheep with weight range of $10 \mathrm{~kg}-30 \mathrm{~kg}$ showed the highest prevalence (97.96\%). Chi-Square Test used to determine the relationships between age and location, had no significant impact on the prevalence of infection. These factors need to be considered in the control of trichostrongylid nematode infection but more emphasis should be given to improvement of hygiene, regular de-worming and frequent diagnosis of trichostrongylid nematode and management of infected animals.
\end{abstract}

Keywords: Age, Consistency of faeces, Gastrointestinal parasites, Grazing time, Sheep, Trichostrongylid nematode, Weight

\section{INTRODUCTION}

Trichostrongylid nematodes are parasites of digestive tract of many animals. There are several Trichostongylidae species in ruminants in different countries across the world. They are considered as one of the major veterinary disease due to the effect of these parasites on livestock health and production. In terms of economics, these parasites cause reduction in growth and development of farm products such as milk, meat, and wool (Bowman, 2008). Some species can also infect human, mainly people living in close association with infected animals (Eslami et al., 2000). The most important genera of trichostrongylid nematodes that live in digestive tract of ruminants include Teladorsagia, Haemonchus, Trichostrongylus, Cooperia and Marshallagia. Out of the above mentioned genera, four infect humans including Teladorsagia Haemonchus, Trichostrongylid nematodes and Marshallagia marshalli. The highest prevalence of these parasites in human seems to be in Iran (Bradbury, 2006). Haemonchosis caused by Haemonchus contortus is a predominant, highly pathogenic and economically important disease of sheep and goats (Mortensen et al., 2003). In Iran, various species of Trichostrongylus have been reported from different hosts including wild herbivores (Eslami et al., 2000), domestic animals (Eslami 1997) and human (Ghadirian and Arfaa, 1975).
Although, compared to the previous decades rate of infectivity in human is currently much lower (Mowlavi et al., 2008), however, information is lacking about the species of trichostrongylus infecting human population and cross-transmission of these nematodes among different animal hosts and human. Gastrointestinal parasites are known to be widespread in Nigeria (Fabiyi, 1973., Eysker and Ogunsusi, 1980) and limit ruminant production in many areas of the country (Eysker and Ogunsusi, 1980; Chiejina, 1987). Clinical records have often been used in monitoring trends in diseases of economic and public health importance in Africa and different agro-climatic zones of Nigeria (Nwanta et al., 2000). Thus, the use of clinical records from veterinary clinics was relied upon as sources of information for the study of seasonal disease prevalence in the sub humid zone of Nigeria. The aim of this investigation was to determine the effect of Trichostrongylid nematode amongst sheep in Benin City, Edo State, Nigeria.

\section{MATERIALS AND METHODS}

The Study Area and Sample Collection

The study area is Benin City, the capital and administrative headquaters of Edo state, founded about 900AD. It is situated at an average height of $200 \mathrm{~m}$ above sea level, located on longitude $50^{\circ} 38^{\prime} 49.42^{\prime \prime} \mathrm{E}$ and latitude $6^{\circ} 20^{\prime} 95.09^{\prime \prime} \mathrm{N}$. 
It covers an area of $19.794 \mathrm{~km} 2$ and a population of $2,159,484$ with that of Benin city estimated at $1,147,188$ (Ministry of Land and Survey, Edo State, 2008). The state majorly relies on animals from the northern part of Nigeria as one of its source of proteins. The study was carried out at various abattoirs in Benin City: Aduwawa, Ugbiyokho, Oluku and Airport road. A structured questionnaire was administered on each sheep, responded by the rearers before being examined. The information obtained include weight, age and time of grazing, A total of 150 sheep faecal samples were collected at different intervals from the Benin municipal abattoirs at Aduwawa, Ugbiyokho, Oluku and airport road. These faecal samples were put in universal plain containers, containing $10 \%$ formaldehyde for preservation. They were properly labeled and then transported to the laboratory for processing.

\section{Processing of Sample}

The faecal samples were processed using stoll's technique to detect the presence of parasites as previously described (Cheesbrough, 2006). Two to three grams of faeces was added to $42 \mathrm{mls}$ of water to make a 1 in 15 dilution in a test tube. For faecal samples which were formed, sodium hydroxide $0.1 \mathrm{~mol} / \mathrm{l}(\mathrm{N} / 10)$ solution was used instead of water. With a rod the faeces were pounded into tiny pieces and mixed with water. The container was capped and shaken hard to complete the mixing. With a wide bore Pasteur pipette, $0.15 \mathrm{ml}$ of the suspension was removed and transferred to a slide. The slide was covered with a cover slip. The entire preparation was examined systematically using $x 10$ objective with the condenser iris reduced to give a good contrast. All the eggs and larvae lying outside the edges of the cover glass were included in the count. The number of eggs counted was multiplied by 100 to give the number of eggs per gram of faeces. For faecal samples that were not formed, the following additional calculation was used to give the number of eggs per gram of faeces:

Fluid specimen. multiplied by 5

Unformed watery specimen........multiplied by 4

Unformed soft specimen............multiplied by 3

Semi-formed specimen.............multiplied by 2

The eggs were identified on the basis of their morphological features as previously described by Soulsby (1982)

\section{Data Analysis}

Statistical analysis Microsoft Excel 2007 and SPSS version 20.0 were used to perform the data analysis. Chi-Square Test was used to compare the differences in prevalence between parameters used in questionnaire.

\section{RESULTS}

A total of 150 sheep were examined and recorded for the prevalence of Trichostrngylid nematodes. The prevalence of eggs and larvae of $\mathrm{H}$. contortus were $71.3 \%$ and $15.3 \%$, Trichostrongylus species were $61.3 \%$ and $7.3 \%$, 0 . ostertagii were $42.7 \%$ and $6.7 \%$ respectively (Table 1$)$. The results in Table 2 revealed an overall prevalence of $103(68.67 \%)$ sheep to be positive out of which $47(31.33 \%)$ were negative. Sheep of age group 12 and above had the highest (71.43\%) prevalence of trichostrongylid nematode infection followed by age group 8-9 years (69.39\%) and age group 10-11 showing the least (67.5\%) prevalence $(P=0.934)$, The age group of the sheep is not significantly associated with the prevalence of infection among sheep in this study.

The relationship between grazing time and infection displayed in Table 3 showed that sheeps that graze in the evening had the highest prevalence of $(82 \%)$ followed by those that graze in the morning $(58.82 \%)$, and those that graze in the afternoon had the least prevalence (33.3\%). The grazing time in relation to infection appears to have significant impact on prevalence of Trichostrongylid nematode in sheep $(P=0.0001)$.

The location of the sheep did not differ significantly with the Trichostrongylid nematode infection ( $p=$ 0.10) among sheep (Table 4). However, Ugbiyokho and Oluku had an infection of $80 \%$ and $74.19 \%$ respectively with airport road having $62.5 \%$ while Aduwawa had the least infection of $60 \%$.

Examination of the faecal sample revealed that the consistency of the faeces was significantly associated with the infection of Trichostrongylid nematode in sheep (Table 5). Faecal samples that were unformed had the highest infection of Trichostrongylid nematode $(85.71 \%)$, followed by faecal samples that were formed $(70.83 \%)$ and semi-formed showed the least infection $(61.54 \%) \mathrm{P}=0.031$. The weight range 10.0 - 30.0 $(\mathrm{kg})$ showed the highest infection $(97.96 \%)$ followed by weight range $30.1-50.0(\mathrm{~kg})$, $(65.67 \%)$ and $50.1-70.0$ showed the least infection $(32.35 \%)$. The weight of the sheep was significantly associated with the infection of Trichostrongylid nematode in sheep examined (Table 6).

Table 1: Prevalence of intestinal nematode parasites in Sheep

\begin{tabular}{|c|c|c|c|c|c|}
\hline \multirow[t]{2}{*}{ Parasite } & \multirow{2}{*}{$\begin{array}{l}\text { Number } \\
\text { examined }\end{array}$} & \multirow[t]{2}{*}{ Negative (\%) } & \multicolumn{2}{|c|}{ Positive } & \multirow[t]{2}{*}{ P-value } \\
\hline & & & $\operatorname{Egg}(\%)$ & Larva (\%) & \\
\hline Trichostrongylid & 150 & $47(31.3)$ & $92(61.3)$ & $11(7.3)$ & 0.000 \\
\hline H. contortus & 150 & $20(13.3)$ & $107(71.3)$ & $23(15.3)$ & 0.000 \\
\hline O. ostertagii & 150 & $76(50.7)$ & 64 (42.7) & $10(6.7)$ & 0.000 \\
\hline
\end{tabular}


Table 2: Prevalence rate of Trichostrongylid nematode in relation to age

\begin{tabular}{ccccc}
\hline $\begin{array}{c}\text { Age } \\
\text { (years) }\end{array}$ & $\begin{array}{c}\text { Number } \\
\text { examined }\end{array}$ & $\begin{array}{c}\text { Number positive } \\
(\%)\end{array}$ & $\begin{array}{c}\text { Number negative } \\
(\%)\end{array}$ & P value \\
\hline $8-9$ & 49 & $34(69.39)$ & $15(30.61)$ & \\
$10-11$ & 80 & $54(67.5)$ & $26(32.5)$ & 0.934 \\
$\geq 12$ & 21 & $15(71.43)$ & $6(28.57)$ & $47(31.33)$ \\
STotal & 150 & $103(68.67)$ & &
\end{tabular}

Table 3: Prevalence rate of Trichostrongylid nematode in relation to time of grazing

\begin{tabular}{ccccc}
\hline Time of grazing & Number examined & $\begin{array}{c}\text { Number positive } \\
(\%)\end{array}$ & $\begin{array}{c}\text { Number negative } \\
(\%)\end{array}$ & P value \\
\hline Morning & 17 & $10(58.82)$ & $7(41.18)$ & \\
Afternoon & 33 & $11(33.3)$ & $22(66.67)$ & 0.0001 \\
Evening & 100 & $82(82)$ & $18(18)$ & \\
Total & 150 & $103(68.67)$ & $47(31.33)$ & \\
\hline
\end{tabular}

Table 4: Prevalence of Trichostrongylid nematode in relation to location

\begin{tabular}{ccccc}
\hline Location & $\begin{array}{c}\text { Number } \\
\text { examined }\end{array}$ & $\begin{array}{c}\text { Number positive } \\
(\%)\end{array}$ & $\begin{array}{c}\text { Number negative } \\
(\%)\end{array}$ & P value \\
\hline Aduwawa & 55 & $33(60)$ & $22(40)$ \\
Ugbiyokho & 40 & $32(80)$ & $8(20)$ & \\
Oluku & 31 & $23(74.19)$ & $8(25.81)$ & 0.10 \\
Airport road & 24 & $15(62.50)$ & $9(37.50)$ & \\
Total & 150 & $103(68.67)$ & $47(31.33)$ & \\
\hline
\end{tabular}

Table 5: Prevalence of Trichostrongylid nematode in relation to consistency of faeces

\begin{tabular}{lllll}
\hline Consistency & Number examined & $\begin{array}{l}\text { Number positive } \\
(\%)\end{array}$ & $\begin{array}{l}\text { Number negative } \\
(\%)\end{array}$ & P value \\
\hline Formed & 24 & $17(70.83)$ & $7(29.17)$ & \\
Semi-formed & 91 & $56(61.54)$ & $35(38.46)$ & 0.031 \\
Unformed & 35 & $30(85.71)$ & $5(14.29)$ & \\
Total & 150 & $103(68.67)$ & $47(31.33)$ & \\
\hline
\end{tabular}

Table 6: Prevalence rate of Trichostrongylid nematode in relation to weight

\begin{tabular}{|c|c|c|c|c|}
\hline Weight (kg) & Number examined & $\begin{array}{l}\text { Number } \\
(\%)\end{array}$ & $\begin{array}{l}\text { Number negative } \\
(\%)\end{array}$ & P value \\
\hline $10.0-30.0$ & 49 & $48(97.96)$ & $1(2.04)$ & \\
\hline $30.1-50.0$ & 67 & $44(65.67)$ & $23(34.33)$ & \\
\hline $50.1-70.0$ & 34 & $11(32.35)$ & $23(67.65)$ & 0.000 \\
\hline Total & 150 & $103(68.67)$ & $47(31.33)$ & \\
\hline
\end{tabular}

\section{DISCUSSION}

Livestock has undeniable role in the human life cycle and ecosystem balance. At times, coexistence of humans alongside livestock over the years has been accompanied by undesirable consequences like zoonotic disease. Trichostrongylid nematodes are parasites of digestive tract of many animals. They are considered as one of the major veterinary disease due to the effect of these parasites on livestock health and production. In terms of economics, these parasites cause reduction in growth and development of farm products, such as, milk, meat, and wool (Bowman, 2008).

The result of this study clearly indicates a high prevalence rate $(68.67 \%)$ of Trichostrongylid nematode infection in sheep examined in 4 different areas in Benin City namely Aduwawa, Ugbiyokho, Oluku and Airport road. Two nematode species of the genus Trichostrongylidae were identified using stoll's technique to detect the presence of parasite. The species were Haemonchus contortus and
Trichostrongylus specie which have been reported to infect these sheep in this part of the country with Haemonchus contortus being the most prevalent helminth parasite. This result was consistent with findings of different researchers in the semi-arid zone of North- Eastern, South-Eastern and South-south Nigeria (Anene et al., 1994a; Fakae, 1990; Fakae and Chiejina, 1993; Nwosu et al., 2007; Elele at al., 2013). The time of grazing, consistency of the faeces and weight of the sheep were significantly associated with the infection of sheep with the Trichostrongylid nematode. The most prevalent species found in this study were Haemonchus contortus with Trichostrongylus specie. This finding is consistent with that of O'connor et al (2006) in Pakistan who monitored the prevalence of infective larvae of gastrointestinal nematode on pastures naturally contaminated with faeces of permanently grazing sheep and found Haemonchus contortus to be the most prevalent parasite followed by Trichostrongylus specie. 
The age of the sheep was not significantly associated with the nematode infection. However, the age group $\geq 12$ had the highest $(71.43 \%)$ infection of Trichostrongylid nematode infection among sheep followed by age group $8-9(69.69 \%)$, while the age group $10-11$ had the least infection (67.5\%) $(P=0.934)$. This high prevalence could be as a result of increased grazing habits, climate, nutritional deficiency, pasture management, hygiene, number of infective larvae and eggs in the environment (Godara et al., 2011).

The time of grazing was significantly associated with the Trichostrongylid nematode infection among sheep $(P=0.001)$. Sheep that grazed in the evening had the highest infection (82\%) followed by those that grazed in the morning $(58.82 \%)$, with those that grazed in the afternoon showing the least infection of $33.3 \%$. This finding is consistent with work done by O'connor et al., (2006) and Manfredi 2006. They highlighted the influence of temperature and humidity in the availability of the infective egg and larvae stating that hot and dry conditions can be lethal for the egg and larvae of the species of Trichostrongylid nematode. Since temperatures in the evenings and mornings are cooler than that of the afternoons, this prevalence could be due to the availability of the parasite at that particular time, temperature and humidity (O'connor et al., 2006)

The location did not have any significant effect on the prevalence of trichostrongylid nematode infection among the sheep examined $(P=0.10)$. Ugbiyokho had the highest prevalence of $74.19 \%$ followed by Oluku and airport road with prevalence of $74.19 \%$ and $62.50 \%$ respectively. Aduwawa had the least prevalence of infection (60\%). This prevalence may be due to the fact that Benin City relies on animals from the northern part of Nigeria for its source of proteins, supplying a good percentage of the daily meat and dairy products in cities and villages in the state. Apart from being the source of animal protein, their wastes are also very important in agriculture (Nwosu et al., 2007). Other factors that may have influenced this are differences in hygienic conditions across the locations, individual sample sizes collected from across the various locations, differences in temperature and humidity.

The consistency of faeces was significantly associated with the prevalence of Trichostrongylid nematode in sheep examined $(P=0.031)$. Sheep with faecal samples that were un-formed showing the highest prevalence $(85.71 \%)$ followed by faecal samples that were formed $(70.83 \%)$, with faecal samples that were semi-formed showing the least prevalence (61.54\%).

\section{REFERENCES}

Anene B.M. Onyekwodiri E.O. Chime A.B. Anika S.M (1994a): Gastrointestinal Parasites in Sheep and Goats of South-eastern Nigeria and Small Ruminant Research 13:187-192.

Bowman D. D. (2008): Georgis' Parasitology for Veterinarians. 9th edn. Saint Louis: Saunders, 464p.
This finding shows that the severity of the infection is indicated in gastroenteritis among the sheep.

The weight of the sheep was significantly associated with the prevalence of Trichostrongylid nematode $(P=0.000)$. Weight range $10.0-30.0 \mathrm{~kg}$ had the highest prevalence of $97.96 \%$ followed by weight range 30.1 - $50.0 \mathrm{~kg}(65.67 \%)$ with weight range 50.1 - $70.0 \mathrm{~kg}$ showing the least prevalence (32.35\%). This finding was consistent with work done by Merial Australia (2011) indicating that emaciation is a result of infection by Trichostrongylid nematode.

\section{CONCLUSION}

Trichostrongylid nematode is one of the major problems affecting health and productivity of livestock. An overall prevalence of $68.67 \%$ Trichostrongylid infection was detected in sheep at various abattoirs in Benin City. Consistency of faecal sample, time of grazing and weight had influence on the prevalence of Trichostrongylid nematode infection. The areas of studies show how workers in the abbatoirs and people who consume the intestinal parts of the animals may be exposed to the infection. Globally, parasitic and other endemic diseases continue to be a major constraint on profitable livestock production. They are rarely associated with high mortality and easily identifiable clinical signs and their effects are usually characterized by lower outputs of animal products, by products, manure and traction; all contributing to production and productivity losses. There were a number of factors associated with the infections of the parasites that need to be considered in the control of the infections.

\section{RECOMMENDATIONS}

However particular emphasis should be given to proper management, regular de-worming and improved hygiene to prevent the parasitic infections in sheep and other animals. Routine diagnosis of Trichostrongy/d nematode and management of infected sheep are advocated. Furthermore, awareness through consolidated sensitization of the importance of the veterinary service in the study areas should be embarked upon in the study areas.

\section{Acknowledgement}

I would like to thank Bayero Journal of Pure and Applied Science for organizing the peer review for the manuscript and the peer reviewer for their comments.

\section{Authors' Contributions}

Zainab and Leonard drafted the manuscripts, with inputs from Yahuza. Zainab prepared the Tables. All authors read and approved the final version of the manuscript

Bradbury R. (2006): An Imported Case of Trichostrongylid Infection in Tasmani \& a Review of Human trichostrongylidi- osis. Australasian College of Tropical Medicine. 7(2): $25-28$ 
Cheesbrough M. (2006): District Laboratory Practices in Tropical Countries Part 1. $2^{\text {nd }}$ ed. Cambridge University press, New York. Pp 199-200.

Chiejina, S. N. (1987): Parasitic Gastroenteritis in Cattle and Small Ruminants: Pathogenesis, Diagnosis and Treatment, Zariya. Vet,2 (2): 45-64.

Elele K. Owhoeli O. Gboeloh L.B (2013): Prevalence of Species of Helminthes Parasites in Cattle slaughtered in Selected, Abbatoirs in Port Harcourt, South-south, Nigeria. International Research on Medical Sciences 1 (2): 010017.

Eslami A, Meydani. And MalekiShZargrzadeh A. (1979): Gastro-intestinal nema- todes of Wild Sheep (Ovisorientalis) from Iran. J.Wildl.Dis.; 15, 263- 265.

Eslami A. (1997): Veterinary Helminthology (Nematoda, Acanthocephala). Vol. III, Tehran University Publication; 892 pp

Eslami A., Changizy E., and Moghadam M. ( 2000): Prevalence of Helminth Infections in the Cape Hare (Lepuscapensis) in Iran. Vet. Res.Comm. 24, 455-45

Eysker M, and Ogunsusi R.A (1980): Observation on Epidemiological and Clinical Aspects of Gastrointestinal Helminthiasis of Sheep in Northern Nigeria during Rainy Season. Res. Vet. Sci. 28: 58-62.

Fabiyi J.P (1973): Seasonal Fluctuations of Nematode Infestations in Goats in the Savanna Belt of Nigeria Bull. Epizootic Dis, Afr., 21: 227-286

Fakae B.B (1990): The Epidemiology of Helminthiasis in Small Ruminants under the Traditional Husbandry System in Eastern Nigeria. Vet. Res. Commun., 14(5): 381-391

Fakae B.B, and Chiejina S.N (1993): The Prevalence of Concurrent Trypanosome and Gastrointestinal Nematode Infections in West African Dwarf Sheep and Goats in Nsukka Area of Eastern Nigeria. Vet. Parasitol., 49: 313-318.

Ghadirian E and Arfaa F. (1975): Present Status of Trichostrongylus in Iran. Am. J. Trop. Med.Hyg. 24(6), 935-941
Ghadirian, E. (1977): Human Infection with Trichostrongylus lerouxiin Iran. Am J. Trop. Med.Hyg. 26(6), 1212-1213.

Godara, R., Sharma, R. L., and Sodhi, S. S (2011): Efficacy of Fenbendazole, Levamisole \& Ivermectin against Gastrointestinal Nematodes in Jamunapari Goats. Journal of Parasitic Diseases 35(2), 29-31

Manfredi, M. T. (2006): Biolgogy of Gastrointestinal Nematodes of Ruminants. Parassitologia, 48(3), 397-401.

Merial Australia. Available http://au.merial.com/disease_information/sh eep/haemo.asp,

September 18, 2011.

Ministry of Land and Survey, Edo State (2008): Edo State Ministry of Land and Survey Annual Report, pp 122.

Mortensen, L.L., Williamson, L.H., Terrill, T.H., Kircher, R., Larsen, M. and Kaplan, R.M., (2003): Evaluation of Prevalence and Clinical Implications of Anthelmintic Resistance in Gastro-intestinal Nematodes of Goats. JAVMA 23: 495-500.

Mowlavi G. R, Mir Ahmadi $H$, Rezaeian M, and Beigom Kia E, (2008): Prevalence of Intestinal Parasites in Yribal Parts of Khuzestan Province during 2005-07. Govar- esh.12(4):219-228

Nwanta, J. A., Hassan, M. I. and Alli-Balogun, J. K. (2000). Epidemiology of PPR in Northern States of Nigeria-An update. Proceedings 25th Nigeria Society of Animal Production Annual Conference 19-23rd March 2000, Umudike, Nigeria

Nwosu C.O, Madu P.P and Richards W.S (2007): Prevalence and Seasonal Changes in the Population of Gastrointestinal Nematodes of Small Ruminants in the Semi-arid Zone of North-eastern Nigeria. Vet Parasitol, 15; 144(1/2): 118-124

O'Connor, L. J., Walkden-Brown, S. W., and Kahn, L. P. (2006): Ecology of the Free-living Stages of Major Trichostrongylid Parasites of Sheep. VeterinaryParasitology, 142(1): 1-15.

Soulsby, E. J. L. (1982): Helminths, Arthropods and Protozoa of Domesticated Animals. 7th Edition, London. 